International Journal of Biology, Pharmacy and Allied Seiences (IJBPAS) 'A Bridge Betuaen Caborat ory and Qundo'

WwW.ijbpas.com

\title{
MACROBENTHIC FAUNA ON THE ROCKY INTERTIDAL SHORE OF SULTAN NAGA DIMAPORO, LANAO DEL NORTE, MINDANAO, PHILIPPINES
}

\author{
MARIA LOURDES DOROTHY G. LACUNA* AND GESREL P. MERLAS
}

Department of Biological Sciences, College of Science and Mathematics, Mindanao State

University-Iligan Institute of Technology, Iligan City, Philippines

*Corresponding Author Email: mileskung12@gmail.com

Received 27 $7^{\text {th }}$ Feb. 2018; Revised 25 ${ }^{\text {th }}$ March. 2018; Accepted $25^{\text {th }}$ April 2018; Available online $1^{\text {st }}$ Sept. 2018 https://doi.org/10.31032/IJBPAS/2018/7.9.4523

\begin{abstract}
Macrobenthic fauna on the rocky intertidal shores of Sultan Naga, Dimaporo, Lanao del Norte were assessed on October, 2017. The transect-quadrat method was employed to assessed macrobenthic communities in the 3 sampling stations. Thirty four taxa of macrobenthos belonging to 4 major groups, namely phylum Echinodermata, Mollusca, Arthropoda and Sipuncula were identified. The molluscan group dominated in terms of species richness by having 21 species, followed by the echinoderms which consisted of 11 species, while both sipinculid and arthropod comprised only of 1 species. Diversity profile showed that stations 1 and 2 were diverse and able to support rich communities of macrobenthic fauna, whereas station 3, which was less diverse, was largely dominated by echinoderms specifically by the ophiuroid group. The reason behind this difference may be attributed to human pressure such as invertebrate gleaning.
\end{abstract}

Keywords: Ophiothrix longipeda, MPA, diversity 


\section{INTRODUCTION}

Intertidal zone is the part of the marine environment that often experience extreme conditions. It undergoes changes of tide levels on a day to day basis thus prolonged exposure to the air, large fluctuations in temperature and salinity, and wave actions are often experienced in this area. But despite these occurrences, it is still able to support variety of life which has the ability to withstand these changes in the environment. Among these life forms are the macrobenthic community which comprises of different species of polychaetes, decopods, molluscs, echinoderms and other groups which are considered as important organisms in the marine environment [1]. These macrobenthic fauna assume critical roles in the ecosystem and the society since they serve as link in the aquatic food chain [2], as good source of proteins for humans and as important material for making of ornaments and jewelry [3]. Considering the significant functions of these organisms and their accessibility in the intertidal zones, they are always easy targets of anthropogenic pressures such as harvesting and tourism activities which often imposed negative impacts on their abundance and diversity [4].

Sultan Naga Dimaporo (SND) is a wellknown municipality of Lanao del Norte because of its rich marine resources. At present there is no existing data on the macrobenthic fauna in the intertidal zone of SND. To address this problem, this study was carried out to provide firsthand information on the diversity and abundance of the intertidal benthic fauna on the three sampling stations along the Sultan Naga Dimaporo. The output of this research may be used for future monitoring purposes and at the same time would encourage the Local Government Units (LGUs) to come up with actions to help conserve and preserve the environment especially the commercially important species.

\section{MATERIALS AND METHODS}

\section{Study area and sampling stations}

Sultan Naga Dimaporo (SND) (formerly Karomatan) is a fifth class municipality in the province of Lanao del Norte, Philippines. It has a latitude of $7^{\circ} 46{ }^{\prime} 59.99^{\prime \prime} \mathrm{N}$ and longitude of $123^{\circ} 44^{\prime} 59.99^{\prime \prime}$ E. It is located at the southwestern part of the province of Lanao del Norte. The municipality of Picong, Lanao del Sur is the southeast boundary of SND, while Tukuran and Aurora in Zamboanga del Sur occupies the western edge. The end point of the famous Illana Bay, which connects to the Celebes Sea, is included in the south margin of SND. It has the longest coastline covering 37, 634 kilometers 
comprising 16 coastal barangays. The tide level in SND, Lanao del Norte usually changes during noontime thus the recorded water temperature in this area is higher which ranges from $33.07^{\circ} \mathrm{C}-33.57^{\circ} \mathrm{C}$. Salinity value ranges between 30-31 ppt, which were common in any coastal biome. These much lower values may be attributed to the presence of Dangulaan river that dilutes the coastal water. Likewise, the $\mathrm{pH}$ value in this area ranges from 8.25-8.48 which were slightly alkaline, a natural $\mathrm{pH}$ values for any marine and coastal waters. Three sampling stations were established within the rocky intertidal zone of Sultan Naga Dimaporo for the assessment of macrobenthic fauna (Figure 1). Station 1 was positioned in barangay Pandanan, while station 2 was located in barangay Pikinit. A marine protected area was formerly established in barangays Pandanan and Pikinit by the local government of Sultan Naga Dimaporo but this was stop due to unavailability of funds. The sediment characteristic in station 1 is made up primarily of fine to medium sand sized particles, while station 2 is mainly composed of sand mixed with small stones. Both stations were characterized by an intertidal flat rich with mixed stands of seagrasses such as Cymodocea rotundata, C. serrulata, Enhalus acoroides, Halodule pinifolia, H. uninervis, Halophila ovalis, and Thalassia hemprichii. The main livelihood in these areas is farming. Station 3 , on the other hand, was established in Barangay Dangulaan where the intertidal flat is characterized by small patches of seagrasses, namely E. acoroides, Halodule pinifolia, $H$. uninervis, Halophila ovalis, $H$. minor and Thalassia hemprichii. Station 3 is also made up of medium sand-sized particles and large and small pebbles were often seen on the intertidal flats.

Field collection of macrobenthic fauna Evaluation for the macrobenthic faunal community was done at the intertidal zones of the three sampling sites. The transectquadrat method was employed during the sampling. Three transects (T1-High stratum, T2-Middle stratum, T3-Low stratum), with lengths of fifty meters (50m) were positioned perpendicular to the shore with $50 \mathrm{~m}$ intervals between each transect. Along each transect, ten $0.5 \mathrm{~m} \times 0.5 \mathrm{~m}$ quadrats were set with five meters interval. Within each quadrat, all macrobenthic faunal organisms present were gathered for identification and counting. Ninety quadrats were laid down on the intertidal zones for the entire sampling sites and the samplings were conducted during low spring tide. Sampling was conducted on October, 2017. All epifaunal macrobenthic species found inside the quadrats along the intertidal zones were gathered by means of 
picking up live organisms. All collected organisms were placed into collecting containers for identification and preserved using $10 \%$ formalin.

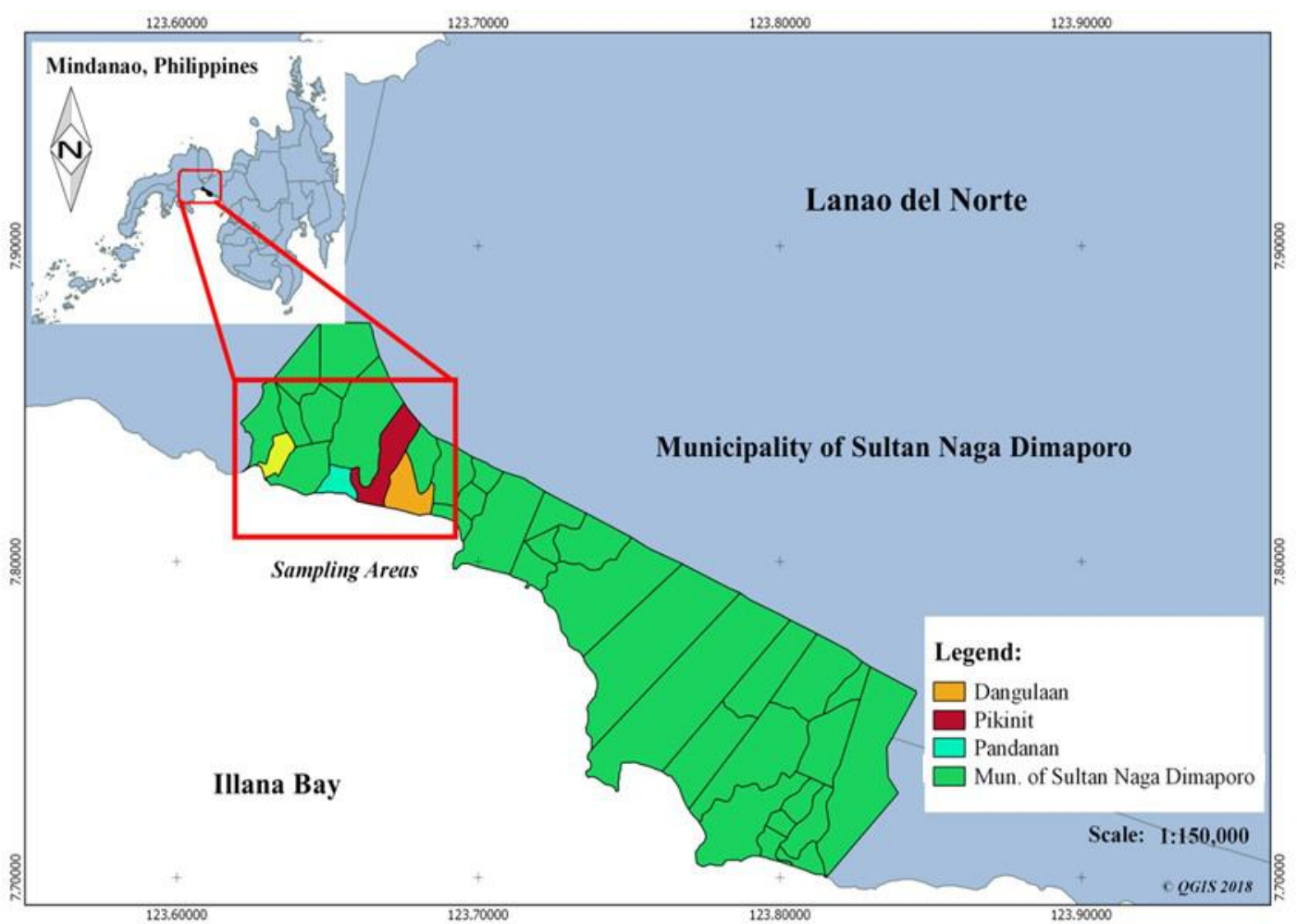

Figure 1: Geographical locations of the three sampling sites: (Station 1) barangay Pandanan, (Station 2) barangay Pikinit, (Station 3) barangay Dangulaan.

\section{Laboratory analysis of macrobenthic}

\section{fauna collected}

Samples of macrobenthic fauna were tallied and identified down to species level. One individual from each species was used as a representative for photo documentation and measurement. Counts were expressed as density and relative abundance. Density was calculated as number of individuals per square meters $\left(\mathrm{m}^{2}\right)$, while relative abundance for each species was calculated as a percent of total macrobenthic species present. Molluscs were identified based from the mollusc book [5] and the illustrated guides to marine gastropods (http://www.gastropods.com) and seashells (www.seashellhub.com, www.jaxshells.com). For echinoderms, identification was based from the echinoderm illustrations [6]. Sipunculid and malacostraca were identified based from world register of marine species (http://www.marinespecies.org).

\section{Statistical Analysis}

Shannon-Weiner Index was used to calculate the species diversity employing the PAST (Paleontological Statistical) software version 2.17 (http://folk.uio.no/ohammer/past/) [7]. 


\section{RESULTS AND DISCCUSION}

\section{Macrobenthic Faunal Composition}

A total of 34 taxa of macrobenthic organisms belonging to 4 major groups, namely Phylum Echinodermata, Mollusca, Sipuncula and Arthropoda, were identified (Table 1). Majority belong to the mollusca group (21 species), of which 18 were gastropods, followed by echinodermata (11 species) and then the sipuncula and arthropoda (both with 1 species). The richest and most abundant taxa among intertidal marine benthic communities in Sultan Naga Dimaporo are the molluscs and echinoderms. The present result is in agreement with other studies done on rocky shores where mollusca and echinodermata were well represented when compared to other phyla $[8,9,10,11]$. Further, among these intertidal macrobenthos, all bivalve species, 9 gastropod species and 1 species of holothuria and 1 species of sea urchin were edible.

\section{Diversity, Richness and Abundance of}

\section{Intertidal Macrobenthic Fauna}

Diversity profile of macrobenthic species in the three sampling stations on the intertidal flats of Sultan Naga Dimaporo, Lanao del Norte is presented in Table 2. The 3 sampling stations reflected differences in species diversity $(H)$, the total number of species (S) and dominance (D) values. Among these sites, station 2 was highly diverse (Shannon, $\mathrm{H}=3.066$ ) as reflected in the highest number of species $(S=27)$. Further, evenness (0.795) value was high but dominance $(D=0.05886)$ value was very low. This may suggest that station 2 supports more species of macrobenthic fauna with no certain species dominating the area. The evenness in the abundance of the different species of macrobenthic fauna in station 2 is well presented in Figure 2. Among these macroinvertebrates, the edible gastropod Lambis lambis attained the highest abundance of $15 \%\left(4.8\right.$ ind $\left.\mathrm{m}^{-2}\right)$, followed in decreasing order by Echinometra mathaie which accounted to about $8 \% \quad\left(2.6\right.$ ind $\left.\mathrm{m}^{-2}\right)$, Ophiothrix longipeda and Strombus luhuanus at 7\% (2.1 ind $\left.\mathrm{m}^{-2}\right)$ and Tectus fenetratus, Spondylus nicobaricus, Pinctada margaritifera, Plagiubrissus grandis at 5\% $\left(1.6\right.$ ind $\left.\mathrm{m}^{-2}\right)$. On the other hand, station 1 displayed a high Shannon $(\mathrm{H}=2.241)$ and evenness $(0.7235)$ values, but low species richness $(\mathrm{S}=13)$ and dominance $(\mathrm{D}=0.1456)$ values as reflected in Table 1 . The result may imply that station 1 still maintain moderately diverse macrofaunal species that are uniformly distributed in the area. 
Table 1: List of macrobenthic fauna on the rocky intertidal shore of Sultan Naga Dimaporo, Lanao del Norte, Mindanao, Philippines

\begin{tabular}{|c|c|c|c|c|c|c|}
\hline \multirow{2}{*}{ Phylum } & \multirow{2}{*}{ Class } & \multirow{2}{*}{ Family } & \multirow{2}{*}{ Species Name } & \multicolumn{3}{|c|}{ Station } \\
\hline & & & & 1 & 2 & 3 \\
\hline \multirow[t]{11}{*}{ Echinodermata } & Asteroidea & Astropectinidae & Astropecten polycanthus (Muller \& Troschel, 1842) & - & + & - \\
\hline & & Ophidiasteridae & Linckia laevigata (Gray, 1840) & + & - & + \\
\hline & & & Nardoa novaecaledoniae (Perrier, 1875) & + & + & - \\
\hline & & Oreasteridae & Culcita novaeguineae (Muller and Troschel, 1842) & - & - & + \\
\hline & & & Protoreaster nodosus (Linnaeus, 1758) & - & + & - \\
\hline & Echinoidea & Brissidae & Plagiobrissus grandis (Gmelin, 1971) & + & + & + \\
\hline & & Echinometridae & Echinometra mathaie (Blainville, 1825) & + & + & + \\
\hline & & Toxopneustidae & Tripneustes gratilla $^{\mathrm{e}}$ (A. Agassiz, 1863) & - & + & - \\
\hline & Holothuroidea & Holothuriidae & Holothuria atra ${ }^{\mathrm{e}}$ (Jaeger, 1833) & + & + & - \\
\hline & & Synaptidae & Synapta maculata (Chamisso \& Eyesenhardt, 1821) & - & + & - \\
\hline & Ophiuroidea & Ophiocomidae & Ophiothrix longipeda (Lamarck, 1816) & + & + & + \\
\hline \multirow[t]{10}{*}{ Mollusca } & Bivalvia & Pinnidae & Atrina vexillum ${ }^{\mathrm{e}}$ (Born, 1778) & - & + & - \\
\hline & & Pteriidae & Pinctada margaritifera $^{\mathrm{e}}$ (Linnaeus, 1758) & - & + & + \\
\hline & & Spondylidae & Spondylus nicobaricus $^{\mathrm{e}}$ (Schreibers, 1793) & + & + & - \\
\hline & Gastropoda & Angariidae & Angaria delphinus ${ }^{\mathrm{e}}$ (Linnaeus, 1758) & + & + & + \\
\hline & & Aplysiidae & Dolabella aurcularia $^{\mathrm{e}}$ (Lightfoot, 1786) & - & + & + \\
\hline & & Burseraceae & Canarium labiatum ${ }^{\mathrm{e}}$ (Roding, 1798) & - & - & + \\
\hline & & Chilodontidae & Herpetopoma atrata $^{\mathrm{e}}$ (Gmelin, 1791) & - & - & + \\
\hline & & Conidae & Conus planorbis $^{\mathrm{e}}$ (Born, 1778) & - & + & - \\
\hline & & Cypracidae & Luria Isabella (Linnaeus, 1758) & + & - & - \\
\hline & & & Luria lurida (Linnaeus, 1758) & - & + & - \\
\hline
\end{tabular}


Table 1 (cont'd): List of macrobenthic fauna on the rocky intertidal shore of Sultan Naga Dimaporo, Lanao del Norte, Mindanao, Philippines

\begin{tabular}{|c|c|c|c|c|c|c|}
\hline \multirow{2}{*}{ Phylum } & \multirow{2}{*}{ Class } & \multirow{2}{*}{ Family } & \multirow{2}{*}{ Species Name } & \multicolumn{3}{|c|}{ Station } \\
\hline & & & & 1 & 2 & 3 \\
\hline & & & Cypraea tigris (Linnaeus, 1758) & - & + & - \\
\hline & & & Cypraea vitellus (Linnaeus, 1758) & + & - & - \\
\hline & & Haliotidae & Haliotis asinina $^{\mathrm{e}}$ (Linnaeus, 1758) & - & + & - \\
\hline & & Muricidae & Chichoreus brunneus ${ }^{\mathrm{e}}$ (Link, 1807) & - & + & - \\
\hline & & Onchidiidae & Onchidella celtica $^{\mathrm{e}}$ (Cuvier, 1817) & + & + & + \\
\hline & & Ranellidae & Cymatium lotorium $^{\mathrm{e}}$ (Linnaeus, 1758) & - & + & - \\
\hline & & Strombidae & Lambis lambis $^{\mathrm{e}}$ (Linnaeus, 1758) & + & + & - \\
\hline & & & Strombus luhuanus $^{\mathrm{e}}$ (Linnaeus, 1758) & - & + & - \\
\hline & & Tegulidae & Tectus fenestratus $^{\mathrm{e}}$ (Gmelin, 1791) & - & + & - \\
\hline & & Trochidae & Trochus maculatus $^{\mathrm{e}}$ (Linnaeus, 1758) & - & + & - \\
\hline & & Volutidae & Cymbiola vespertilio $^{\mathrm{e}}$ (Linnaeus, 1758) & - & + & - \\
\hline Sipuncula & Sipunculidea & Golfingiidae & Sipunculus nudus $^{\mathrm{e}}$ (Linnaeus, 1766) & + & + & - \\
\hline Arthropoda & Malacostraca & Pilumnidae & Pilimnus vespertilio (Fabricius, 1793) & - & - & + \\
\hline
\end{tabular}

Legend: + present; - absent; e edible 
Table 2: Diversity profiles of the three sampling stations on the rocky intertidal shore of Sultan Naga Dimaporo, Lanao del Norte, Mindanao, Philippines

\begin{tabular}{cccc}
\hline Diversity & \multicolumn{3}{c}{ Station } \\
\cline { 2 - 4 } Index & 1 & 2 & 3 \\
\hline Taxa (S) & 13 & 27 & 12 \\
Individuals & 25 & 61 & 68 \\
Dominance (D) & 0.1456 & 0.05886 & 0.3564 \\
Shannon (H) & 2.241 & 3.066 & 1.58 \\
${\text { Evenness }\left(\mathrm{e}^{\wedge} \mathrm{H} / \mathrm{S}\right)}$ & $\mathbf{0 . 7 2 3 5}$ & $\mathbf{0 . 7 9 5}$ & $\mathbf{0 . 4 0 4 8}$ \\
\hline
\end{tabular}

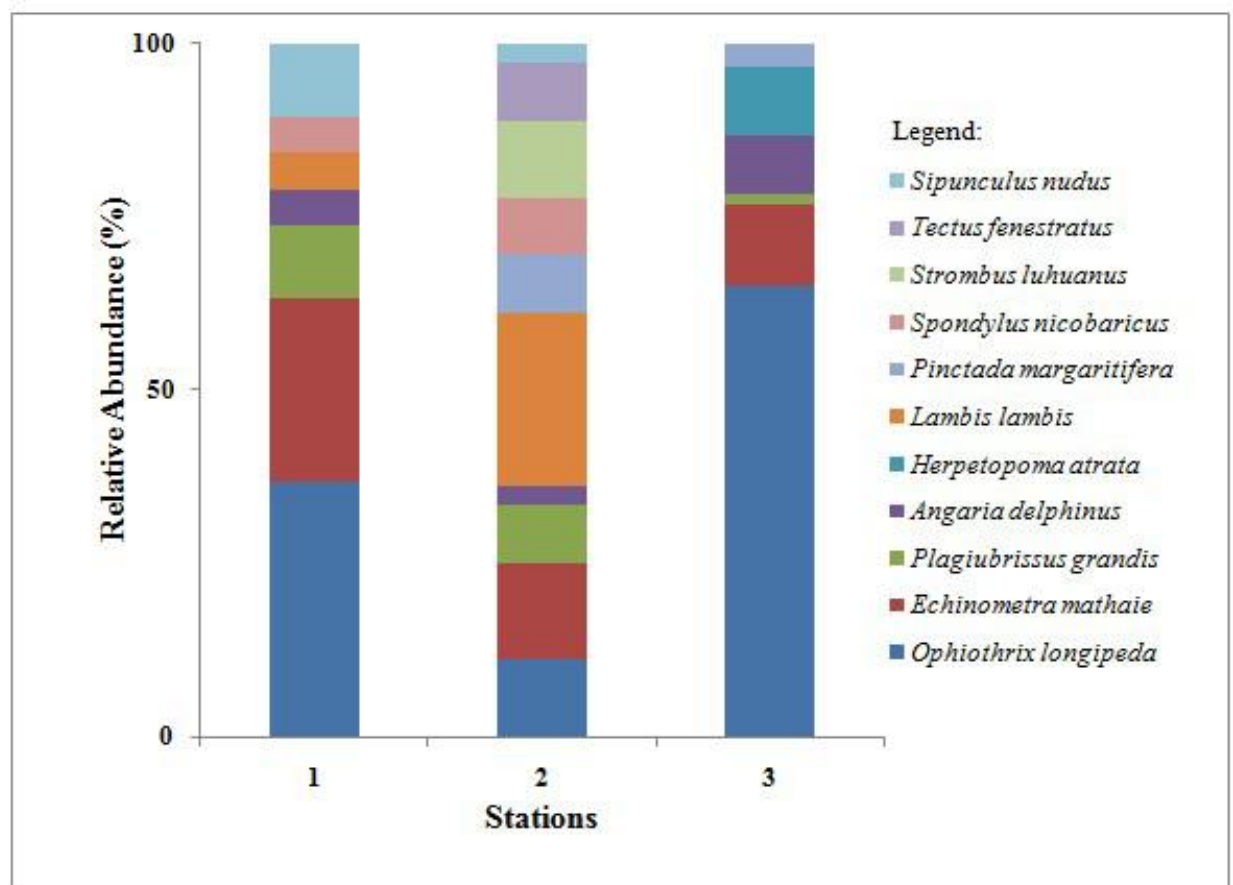

Figure 2: Macrobenthic fauna with relative abundances of $>5 \%$ of the total population in the 3 sampling stationson the rocky intertidal shore of Sultan Naga Dimaporo,

Lanao del Norte, Mindanao, Philippines

Among the macrofauna assemblage (Figure

2) that stand out in station 1 are the following: O. longipeda at 28\% (3.7 ind $\mathrm{m}^{-}$ $\left.{ }^{2}\right)$, E. mathaie at $20 \% \quad\left(2.6\right.$ ind $\left.\mathrm{m}^{-2}\right), P$. grandis and Sipunculus nudus both at $8 \%$ $\left(1.6\right.$ ind $\left.\mathrm{m}^{-2}\right)$. However, station 3 recorded the lowest diversity (Table 1), number of species, and evenness values, but highest dominance $(D=0.3564)$ value, an indication that the area consisted of low macrobenthic fauna assemblage and that this assemblage is mainly dominated by some species. In particular, the species Ophiothrix longipeda is solely responsible for this dominance in station 3 (Figure 2) since they comprised the major bulk ( $57 \%$ or 20.8 ind $\left.\mathrm{m}^{-2}\right)$ of the macrobenthic population in the said station. Other species with relative abundance of $\geq 5 \%$ are Herpetopoma atrata $(10 \%$ or 3.2 ind $\left.\mathrm{m}^{-2}\right)$, E. mathaie $\left(8.8 \%\right.$ or 2.7 ind $\left.\mathrm{m}^{-2}\right)$, and Angaria delphinus ( $7 \%$ or 2.6 ind $\mathrm{m}^{-2}$ ). In general, our data showed that stations 1 
and 2 maintain rich communities of macrobenthic fauna, while station 3 supports relatively few species of macrofauna with the ophuiorids being the dominant group in the population. It is common knowledge that a marine protected area (MPA) was formerly established by the local government of Sultan Naga Dimaporo in stations 1 and 2, however due to unavailability of funds its operation was ceased several years ago. It is probable that the strict implementation of the former MPAs during its years of operation may greatly influenced the minds and hearts of the people living along these areas such that it is second nature for them to protect the marine resource, hence leading to the continued preservation of macrobenthic faunal population. Studies have showed improved quality and quantity of marine resources inside a protected fish sanctuary or marine protected areas (MPAs) when compared to those in non MPAs $[12,13]$. Moreover, it was observed that only few residents were living along the coast in these two stations and that their main livelihood is farming. This situation may have likewise help in the preservation and conservation of intertidal macrobenthic faunal assemblage in these two sites because harvesting of intertidal macroinvertebrates were non-existent. On the contrary, high population of people were observed living along the coastline in station 3 where their source of income and daily supply of food being obtained from daily gleaning of macroinvertebrates found in the intertidal zone. Although we did not include the assessment of gleaners in the present study, it is highly probable that the low species diversity and richness noted in station 3 may be attributed to rampant gleaning activities we noticed during our field samplings in this station where edible molluscs and echinoderms were being gathered but leaving behind non-edible species.

\section{CONCLUSION}

Mollusc and echinoderm fauna are the most common macrobenthic community in the rocky intertidal shores of Sultan Naga Dimaporo. The diversity profiles showed stations 1 and 2 as diverse areas when compared to station 3 which is less diverse because the community is solely dominated by echinoderms specifically by the ophiuroid group. It is suggested that the strict implementation of the former MPAs during its years of operation may have a strong influence on the residents living along the coast in stations 1 and 2 so that eventhough the MPAs were no longer operational, the people still thrive to protect and preserve these intertidal animals by not indulging in gleaning or invertebrate collection. It is recommended to take into 
account the monthly monitoring of community abundance and distribution of gleaned or target species for harvest between changes in seasons (i.e. NE and SW monsoons). Further, since environmental parameters (i.e. $\mathrm{pH}$, salinity, temperature) may possibly put pressures on these fauna, we recommend that these parameters be assessed together with the macrobenthic population between seasons.

\section{REFERENCES}

[1] Libres M. C., Species diversity of macrobenthic invertebrates in mangrove seagrass ecosystems of eastern Bohol, Philippines, Asia Pacific Journal of Multidisciplinary Research, 3(5), 2015, 128-134.

[2] Burkepile D. E, Hay M. E., Predator release of the gastropod Cyphoma gibbosum increases predation on gorgonian corals, Oecologia, 154(1), 2007, 167-173.

[3] Santhiya N., Baskara S. S., Gayathri M., Dhanalakshmi M., Economic Importance of Molluscs, Research Environment and Life Sciences, 6(4), 2013, 129-132.

[4] Vaghela A, Bhadja P, Ramoliya J, Patel N, Kundu R., Seasonal variations in the water quality, diversity and population ecology of intertidal macrofauna at an industrially influenced coast, Water
Science and Technology, 61(6), 2010, 1505-14.

[5] Springsteen F.J., Leobrera F.M., Shells of the Philippines, Carfel Shell Museum, Philippines, 1986, 377.

[6] Brueggeman P., Diving under antarctic ice: A History. Scripps Institution of Oceanography, Technical Report, 2003.

[7] Hammer O., Harper D. A. T., Ryan P. D., PAST: paleontological statistics software package for education and data analysis, Palaeontologia Electronica, 4, 2001, 1-9.

[8] Medrano M. G. T., Diversity of macrobenthic invertebrates in the intertidal zone of Barangay Tagpangahoy, Tubay, Agusan Del Norte, Philippines, International Journal of Technical Research and Applications, 19, 2015, 5-9.

[9] Bhadja P., Paresh P., Rahul K., Community structure and distribution pattern of intertidal invertebrate macrofauna at some anthropogenically influenced coasts of kathiawar peninsula (India), Advances in Ecology, 2014, 2014, 11.

[10] Londoño-Cruz E., López de MesaAgudelo L. A., Arias-Galvez F., 
Herrera-Paz, D. L., Prado, A.,

Cuellar L., Distribution of macroinvertebrates on intertidal rocky shores in Gorgona Island, Colombia (Tropical Eastern Pacific), Revista de biologia tropical, 62(1), 2014, 189-198.

[11] Ryu S. H., Jang K. H., Choi E. H., Kim S. K., Song S. J., Cho H. J., Ryu J. S., Kim Y.

[12] M., Sagong J., Lee J. H., Yeo M. Y., Bahn S. Y., Kim H. M., Lee G. S., Lee D. H., Choo Y.

[13] S., Pak J. H., Park J. S., Ryu J. S., Khim J. S., Hwang, U. W, Biodiversity of marine invertebrates on rocky shore of Dokdo, Korea, Zoological Studies, 51(5), 2012, 710-726.

[14] Halpern B. S., The impact of marine reserves: do reserves work and does reserve size matter?, Ecological Applications, 13(1), 2003, 117-137.

[15] Gonzales B. J., Becira J. G., Galon, W. M., Gonzales M. M. G., Protected versus unprotected area with reference to fishes, corals, macroinvertebrates, and CPUE in Honda Bay, Palawan, 6, 2014, 4259. 